\title{
Selective use patterns of woody plant species by local communities in Mumbwa Game Management Area: A prerequisite for effective management of woodland resources and benefit sharing
}

\author{
Chansa Chomba ${ }^{1 *}$, Vincent Nyirenda $^{2}$, Mitulo Silengo ${ }^{1}$ \\ ${ }^{1}$ School of Agriculture and Natural Resources, Disaster Management Training Centre, Mulungushi University, Kabwe, Zambia; \\ *Corresponding Author: chansachomba@rocketmail.com, ritachansa@yahoo.com \\ ${ }^{2}$ Zambia Wildlife Authority, Directorate of Research P/B 1 Chilanga, Zambia
}

Received 27 August 2013; revised 27 September 2013; accepted 5 October 2013

Copyright (C) 2013 Chansa Chomba et al. This is an open access article distributed under the Creative Commons Attribution License, which permits unrestricted use, distribution, and reproduction in any medium, provided the original work is properly cited.

\begin{abstract}
Selective patterns of human uses of woody plants in Mumbwa Game Management Area were investigated using quantitative survey methods. Major causes of human encroachment into the wildlife zone were assessed so that appropriate management actions could be taken to ensure continued supply of goods and services to the local community. Woody plant species were found to be diverse with 93 species recorded in the study area. Of these, the community utilized $92(99 \%)$ in different ways. Trees were cut for various reasons, major ones being; building poles, fire wood, fibre, fruit collection, medicine, bee honey collection, house hold tools and utensils and clearing for agriculture. Clearing for agriculture was the most damaging, because it involved removal of below and above ground woody biomass of all sizes and suppression of their regeneration during cultivation in subsequent years. Of the recorded human uses, 2366 kg of woody plant material was consumed per head $/{ }^{\mathrm{yr}-1}$ as fire wood. The day to day consumption of firewood varied with season. In the cold season (May-August), a $26 \mathrm{~kg}$ (mean weight) bundle of firewood was consumed in three days while in the warm season it lasts five days. Certain species were particularly selected; Julbernardia paniculata, Pericopsis angolensis, Brachystegia speciformis, Brachystegia boehmii, Julbernardia globiflora, Brachystegia longifolia, and Pteleopsis anisoptera. In building and construction, differences were observed in the spe-
\end{abstract}

cies and size of poles was used. The mean sizes of roofing poles were 3.5 metres long and $\mathbf{0 . 1 8}$ metres mid-length girth. Wall poles were 2.4 metres long and $\mathbf{0 . 4 0}$ metres mid-length girth. For the main house of about two rooms each, there were an average number of 48 poles in the roof $\left(45,859.2 \mathrm{~cm}^{3}\right)$ and $28\left(284,653.6 \mathrm{~cm}^{3}\right)$ in the wall. Clearing for agriculture was the main cause of damage to woody plants in the Game Management Area. The extension of human settlements into the wildlife zone and towards the Itezhi-tezhi road is likely to increase loss of woody vegetation, and will have a negative impact on the habitat for wildlife.

Keywords: Utilization; Woody Plants; Local Community; Agriculture

\section{INTRODUCTION}

Woody plants are central to the livelihood systems of thousands of rural and urban dwellers in Africa [1-8]. A range of products from woodlands support rural living by way of medicines, food, building timber and fuel (Figure 1). Ecologically, trees play an important role in controlling soil erosion by intercepting rain drops, providing a habitat to many organisms and also creating a micro climate which both man and beast utilize (Figure 2). They are also central to the spiritual needs of people, with specific trees even blocks of woodland being conserved by local communities for cultural reasons, for example, burial groves. Sacred groves associated with spirits of the dead or with territorial deities are found not only in Zambia but also in other countries throughout the miombo 


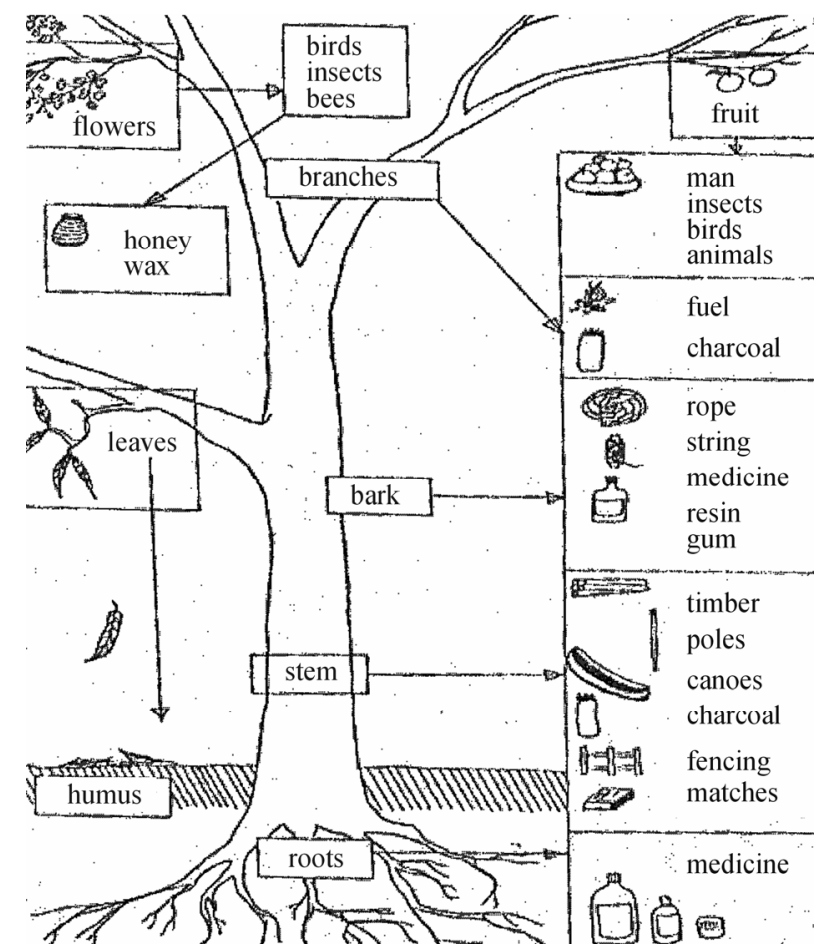

Figure 1. Different human uses of woody plants (source: Storrs, 1968).

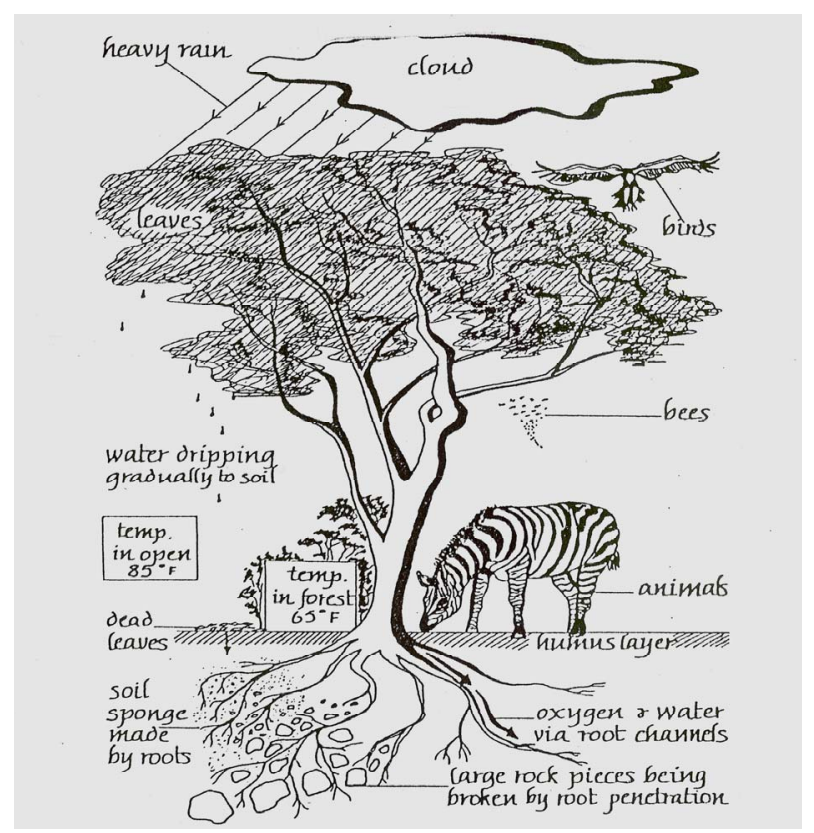

Figure 2. Different ecological uses of woody plants (source: Storrs, 1968).

eco-region of east and southern Africa [7].

Woodlands also provide products for towns and cities in Zambia. The most important of these is fuel, but also a source of income are non-fuel timber products including honey, bees wax, edible fruits, edible insects, vegetables, game meat, mushrooms, traditional medicine, and wood for handicraft [8-10]. These goods and services create a demand for woody plants and even when the woodlands are located in an inhabitable escarpments and mountainous landscapes of rugged and rocky nature, or are protected by law such as forest reserves, zoned Game Management Areas or National Parks. They are still legally or illegally accessed for collection of various products [11].

In Zambia, there is a growing concern about deforestation. An estimated $0.5 \%$ of the country's woodlands were lost each year [12]. The figure could even be higher at the moment. Around large human settlements, this loss may be considerably higher. Although fires, especially those late in the season, are one of the principal causes of deforestation, and it is accentuated by other anthropogenic factors. The cutting of trees for firewood and charcoal, combined with clearing for agriculture for instance, are additional causes of deforestation around large human settlements, towns and major fishing areas [12]. Traditionally, firewood was collected from dead wood on the ground, often as old trees that have died of natural causes or as a product of land clearance for agriculture, but with the increase in human population, this is becoming less practicable and live trees are now being cut for fuel wood. Firewood cutting however, does not amount to complete clearance of woody biomass, as some of the species are preferred to others, so the true extent of the problem is not immediately obvious, and this has led to lack of awareness among the public. Other problems include declining fallow periods and the clearance of land for both small and large scale agriculture [12-16].

In protected areas such as Mumbwa Game Management Area, where conditions of multiple property rights exist with the state through ZAWA legally co-opting traditional/customary tenure to create a statutory system overlaid on a traditional one, the exploitation of resources is often antagonistic. This is not unique to Zambia, as in many parts of Africa, governments lay claim to greater amounts of land and other natural resources than they can effectively control. The result is that authority and management continue to be compromised and open access tendencies thrive.

The local community in Mumbwa GMA, however, benefit from the natural resources, through the provision of social facilities such as schools, clinics as well as employment facilitated by revenue accrued from trophy hunting. Such revenues are shared on 50:50 basis between ZAWA and Community Resource Boards (CRBs). With regards to forest products in Protected Areas however, management is generally centralized under ZAWA and the Department of Forestry (FD). As a result, local people tend to share the proprietorship of the forests with the state in conflicting circumstances. In many instances, local communities permit timber cutting in GMAS without seeking ZAWA's authorization which is contrary to 
the Zambia Wildlife Act No. 12 of 1998. The other indication of resentment is the increasing levels of illegal settlements in the wildlife zone. The increased numbers of illegal settlers and the accompanying clearing for agriculture and other extractive uses of vegetation exacerbate habitat transformation/loss, weakening the status of Mumbwa GMA as a buffer to Kafue National Park. An effective GMA as a buffer zone, is intended among other things to; 1) extend those habitats contained within the National Park, 2) provide for the needs of threatened and endangered species of animals, 3) act as additional habitat outside the National Park boundary thereby enhancing the capacity to contain wildlife species likely to move out of the National Park [17,18], and 4) sustain trophy hunting and limited photographic safaris from which local communities benefit. The GMA is also supposed to serve other environmental protective functions such as soil and water conservation [18,19]. If a buffer zone is encroached by human settlements, its ecological functions wane. This is because human settlements in most instances have predictable needs for firewood and building timber, such that even when settlements are on the periphery they would eventually expand deeper into the wildlife zone and overtime, the GMA would fail to meet their requirements and settlers would seek such resources from the National Park itself $[8,19,20]$.

The aim of this study therefore, was to assess human use of the woody plants in Mumbwa GMA, focusing on clearing for agriculture, wood fuel and building poles and to a lesser extent other uses such as honey collection, medicines and house hold tools. This study targeted woody plants because they take longer time to grow than herbaceous plants. Popular woody species that are habitat specific slow growing and slow reproducing and which are debarked or dug out for dyes, medicine, food or horticultural purposes are particularly vulnerable to over harvesting. Studies carried out in Tanzania showed that effects of harvesting of trees for building materials or fuel wood would be more apparent if there was; complete removal of woody biomass, low levels of recruitment and suppression of coppices [11,21,22]. Harvesting of poles and laths for instance utilize much smaller stem size classes than the timber industry, but nevertheless can impact on tree recruitment and woodland structure [21, 23].

In order to develop appropriate management strategies that would ensure continued supply of goods and services on a sustainable basis, the human use of woody plants as well as their ecological importance in maintaining soils and biota should be understood. Figures 1 and $\mathbf{2}$ demonstrate the different ecological and human uses of woody plants which should form the basis for the need to protect them, which is why this study is important.

\section{METHODS AND MATERIALS}

\subsection{Study Area}

Mumbwa GMA is situated on the eastern boundary of Kafue National Park. It lies between $14^{\circ} 58^{\prime}$ and $15^{\circ} 18^{\prime}$ south and $25^{\circ} 58^{\prime}$ and $26^{\circ} 58^{\prime}$ east and covers an area approximately $3370 \mathrm{~km}^{2}$ in extent (Figure 3).

Relief and drainage comprise of an undulating landscape with a general elevation of approximately $1000 \mathrm{~m}$ above sea level broken only by a ridge of over $1200 \mathrm{~m}$ a.s.l. in a SW-NE direction. The Nansenga and Nagoma Rivers dominate the drainage system.

Mean annual rainfall ranges from $1000 \mathrm{~mm}$ with mean annual rainy days of 80 except for the southern tip which has 70 days. The mean date for the onset of rains is $10^{\text {th }}$ November and the mean date for retreat is $20^{\text {th }}$ March. The evapouration rates reach the peak of $295 \mathrm{~mm}$ in October, falling to $115 \mathrm{~mm}$ in February. These figures may however, change in view of the threats of global warming and changing weather patterns.

The geology is underlain predominantly by the KarrooGranite complex flanked by a series of Katangan metasediments, shales, sandstones and siltstones to the northwest and southwest. An inlier of Katanga rocks is found towards the northwest corner of the GMA $[8,24]$. The GMA soils, however, are of different types with $88 \%$ of the area being covered by Orthi-eutric dystric leptosols, Chromic-haplic uxisols. These consist of well drained, shallow to moderately shallow, dark brown to dark yellowish brown, rocky, fine loamy to clayey soils. A small portion (approximately 12\%) in the north western corner consists of moderately shallow, brown to yellowish brown, friable, clayey soils with a very weak profile development and in places imperfectly drained Orthic-dystric regosols $[8,24]$.

\subsection{Vegetation}

The vegetation of Mumbwa GMA is typical of a plateau landscape, with the total number of woody plants being 450 - 500 species [8,25-27]. It is a typical miombo classified as woodland of plateau and hill comprising the following; Pure Julbernardia paniculata woodland, rarely with Brachystegia longifolia of Brachystegia floribunda; pure Brachystegia longifolia rarely with Julbernardia paniculata or Brachystegia spiciformis; almost pure Brachystegia utilis woodland occasionally with a little Julbernardia paniculata, Brachystegia longifolia or Brachystegia spiciformis; almost pure Brachystegia boehmii woodland occasionally with a fair amount of Julbernardia paniculata; pure Brachystegia spp woodland with little Julbernardia paniculata or Brachystegia longifolia; pure Brachystegia bussei woodland with Sterculia spp; almost low pure Brachystegia spiciformis woodland on hill tops; Julbernardia paniculata- 


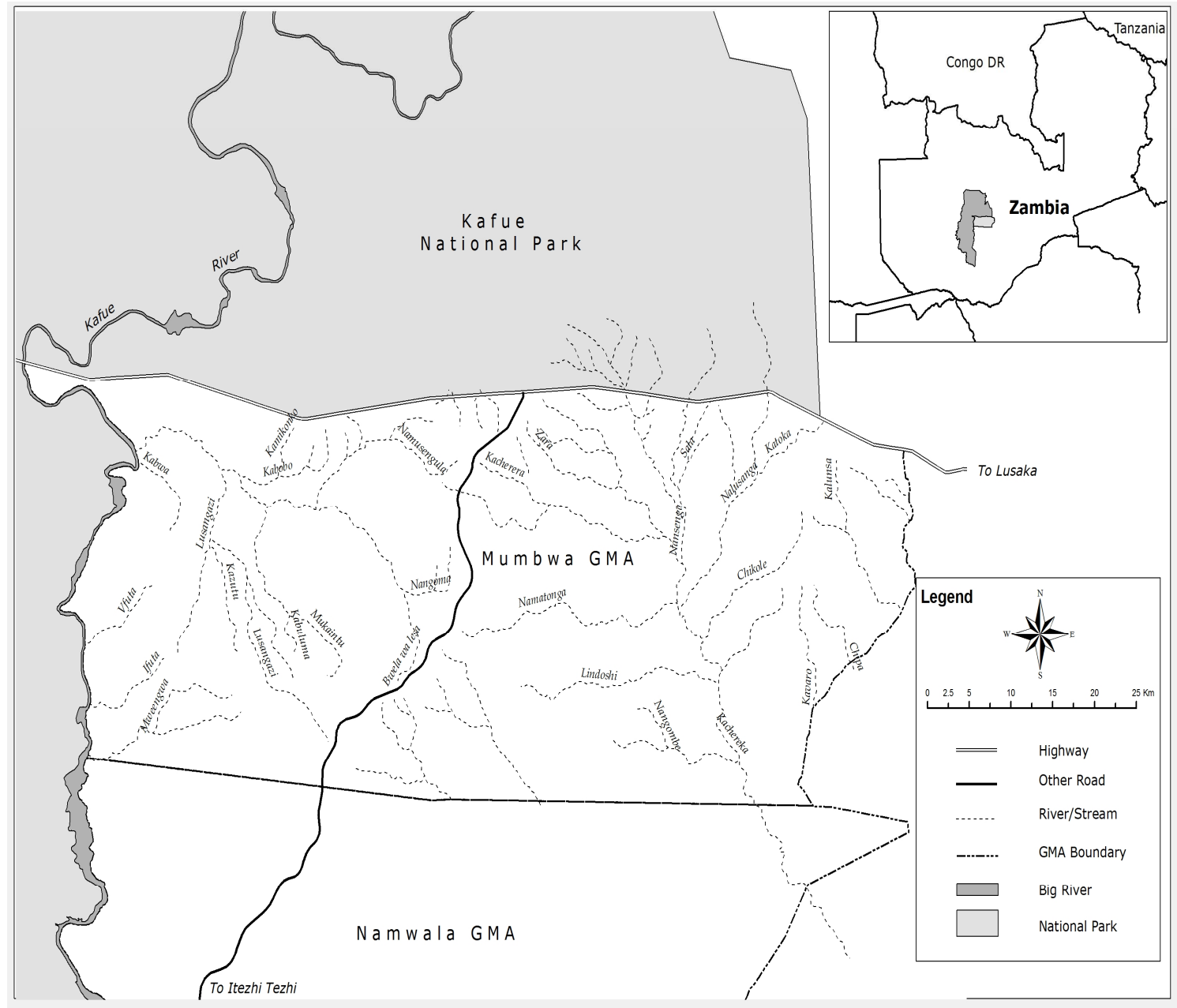

Figure 3. Location of study area, Zambia.

Brachystegia longifolia woodland with varying percentages of the two co-dominants; mixed miombo woodland and various mixtures of almost all plateau species of Brachystegia with Julbernardia paniculata.

The chief characteristic of the miombo woodland in the study area was its openness below canopy. Small trees and shrubs were scattered so that visibility within the woodland was high. The chief associates of Julbernardia and Brachystegia species were Acacia macrothyrsa, Albizia antunesiana, Azanza garckeana, Bauhinia petersiana, Clerodendrum glabrum, Cordia spp, Grewia flavescens, Margaritaria spp, and Ximenia caffra. Acacia scheinfurthii, Capparis tomentosa, Clematis brachiata, Hippocratea indica, Jasminum stenolobum, Turbina shirensis and Vernonia aurantiaca were the most prominent climbers.

The Acacia-Albizia woodland was mainly found on the alluvial plains where it formed very open woodland with a few shrubs but abundant tall grass. The dominant species were Acacia and Albizia spp, which occurred in pure or almost pure stands accompanied by Ficus capen- sis, Combretum imberbe, Lonchocarpus capassa, Combretum ghasalense, Piliostigma thonningii, and Zizyphus abyssinica.

\subsection{Human Settlements}

Settlers were either randomly distributed as determined by water availability or linearly distributed along main streams, Lusaka-Mongu highway and access roads. The population was densest between the Lutale River and Nansenga stream. Since the 1990s however, settlements have been spreading towards Chungu stream into the wildlife zone. The total human population in the GMA was estimated at 6000 in 2000 but had increased to more than 10,000 by 2011 .

\subsection{Field Methodology}

\subsubsection{Vegetation Use Assessment}

Transects $1 \mathrm{~km}$ long each were laid out at randomly located points along the Nansenga River which forms the boundary between settlement and wildlife zones. At each 
of the random points along the boundary, transect lines were laid out perpendicular to each other for $1 \mathrm{~km}$ into the settlement and wildlife zones respectively. There were ten transects in each zone and ten plots along each transect line. The modified Whittaker plot method was used [28]. Along each transect line, sample plots were located at random $[29,30]$. The plots were used to sample woody plants greater than $10 \mathrm{~cm} \mathrm{dbh}$. The diameter at breast heigh was taken to be 1.3 metres above ground $[29,30]$ The variable measurements included; girth, height and crown diameter $[29,30]$. In measuring dbh circumference was measured and converted later using the formula; $\mathrm{C}=\mathrm{D} \pi$. Thus $\mathrm{D}=\mathrm{C} / \pi$. The basal area (BA) being calculated as $\pi r^{2}$ while volume was calculated as $\pi \mathrm{r}^{2} \mathrm{~h} \times 1 / 3$; where $\mathrm{C}=$ circumference, $\mathrm{D}=$ diameter, $\mathrm{H}=$ height, $r=$ radius and pie $(\pi=3.14)$ is a constant.

Where tree stems branched below dbh, the individual stems were counted and their measurements combined as also applied in other similar studies [8,29]. If the branching was at ground level, each stem was treated as an individual tree. This was because measurements used to calculate basal area were taken at 1.3 metres above ground level. Tree height was measured using a tree height measuring rod. Canopy cover was measured using a 100 metre measuring tape laid on the ground from one edge of the crown to the other $\mathrm{D}_{1}$, the second measurement being taken perpendicular to the first one as $\mathrm{D}_{2}$.

All trees of circumference greater than $10 \mathrm{~cm}$ dbh in each $25 \mathrm{~m} \times 25 \mathrm{~m}$ plot were examined for any human induced damage. Human damage categories were developed as described below to give an indication of the frequency with which a species was the most diverse in its uses and whether it may be in danger of over exploitation. Damage categories were classified as; coppice when the stem was cut below $50 \mathrm{~cm}$ above ground level; pollard when cut at above $50 \mathrm{~cm}$; lop when branch was cut; strip when bark had been removed as in fibre collection and scarred when there are identifiable axe or other human made tool marks on the stem or branch. Difficulties were encountered where vernacular names referred to large genera and many species with one common name for different species. This was the case with Combretum and Terminalia species. Specimens of plant species not identified in the field were taken to the herbarium for verification. Data collected was analysed using a Minitab 14.0 computer software programme. This survey was carried out in 1998 and 2011/12 seasons.

\subsubsection{Questionnaire Survey}

The survey covered villages located in the settlement zone of the GMA. The villages sampled were within 1 $\mathrm{km}$ of the wildlife zone boundary. This closeness to the wildlife zone boundary allowed the assessment to determine the influences that villagers might have on the wildlife zone. Households resident at the same locality for no less than 12 calendar months were interviewed. A pre coded questionnaire was used with the last two questions being open ended, designed to reveal the many facets of the respondents' attitude towards the GMA.

\subsubsection{Enumerators}

To ensure gender balance, three female and three male enumerators were engaged from within the communities' resident in the GMA. The six enumerators took measurements of buildings and fire wood as well as participating in the Participatory Rural Appraisal. The advantage was that they were familiar with local species and were knowledgeable of and known to the community. Prior to starting work, the enumerators were trained for a period of two weeks during which trial questionnaires were conducted to determine their suitability for the local community.

\subsubsection{Participatory Rural Appraisal}

Groups of people resident in the GMA of different age groups and gender depending on the topic being discussed were gathered together and information collected from them by asking questions regarding natural resource utilization. Interviewees were assured that any answer given would not lead to any criminal proceeding. The PRA took advantage of Sunday masses, wedding parties and other public gatherings as organizing meetings solely for PRA were non responsive. The number of questions was limited depending on the occasion as it was found that asking too many questions led to inaccurate responses.

\subsubsection{Building Materials and Firewood Survey}

For a given human use, some plants were preferred by local people to others and are therefore, sought out and used. This provided the researchers with an indication of the relative importance of each species to the local community. Species preferences were also determined from the house hold consumption surveys, which gathered data on the frequency with which species were used for certain purposes, the preferred species for each human use and reasons for their selection.

\subsubsection{Measuring Wooden Structure}

Building materials were divided into two major categories: roofing poles and wall poles for houses and floor pole, horizontal and upright poles for grain racks (Figure 4). Measurements of 32 houses randomly located in different villages were made. In each building; house, grain rack or granary, species used were identified, mid length girth taken in $\mathrm{cm}$, and length of pole measured in $\mathrm{cm}$. For walling poles, the examiner excavated (with the permission of the owner) the pole to expose the part buried in 


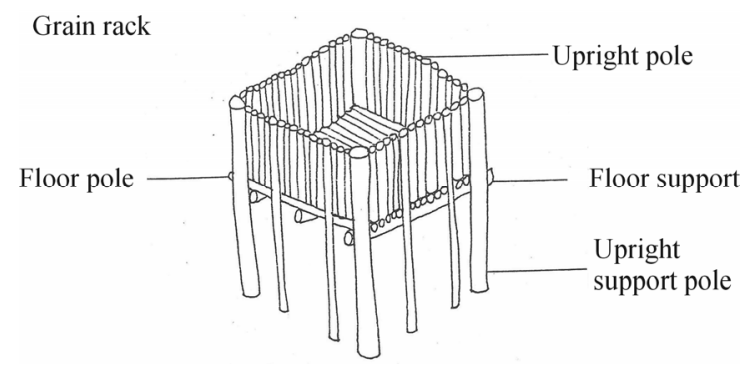

Figure 4. Conceptual use of woody plants in grain rack construction, Zambia 2012 (modified after: Chansa, 2000).

the ground to measure the length of the pole and how deep the poles were buried in the ground. Permission was sought from each house hold to enter their house and take measurements of roofing and wall poles.

\subsubsection{Measuring Firewood}

Units of head loads, wheelbarrow, bicycle and scotch cart towed by oxen or donkeys were measured. Bundles of firewood were weighed and the number of poles counted. In order to investigate the methods of fire wood collection used, the three female enumerators accompanied women on firewood collection trips. This is because women were the main firewood collectors as recorded during PRA and questionnaire survey. The enumerator allocated all the fire wood collected into categories as, felled trees, taken from woodpiles made during clearing of fields for agriculture, from standing dead trees, or gathered from the ground. Group meetings were also held to consolidate the commonest firewood collection methods. In each village, species preferences and uses of firewood were recorded from the bundles of firewood examined. All bundles of firewood examined were weighted to determine weight in $\mathrm{kg}$.

\subsection{Limitations}

Determining species preference and classifying damage categories involved in some instances, relatively arbitrary approaches and subjective assignation of numerical values to different criteria. Although this approach has been criticized by some researchers, the aim in this study was to obtain relative and not absolute values of species' preferences and damage and was therefore effective in achieving this goal. The boundary between the wildlife and settlement zones was also often arbitrary except where it was demarcated by a prominent physical feature such as a river.

\section{RESULTS}

\subsection{Use of Woody Plants by Local Communities}

In this study 93 plant species were recorded and of these 92 (99\%) were used by the local community. In fact, each one of them had more than one use (Table 1). Fourteen were recorded for medicinal and magical uses, 21 for tools and utensils, 25 for wall poles, 33 for roofing poles, seven for firewood, 13 for fruit trees and five were reserved for hanging bee hives.

\subsection{Differences in Woody Plant Density between Settlement and Wildlife Zones}

There were more stems and trees per hectare in wildlife zone than settlement zone. Three species were recorded to have equal relative frequency of $5 \%$ in both settlement and wildlife zones. These were; Julbernardia panniculata, Brachystegia boehmii and Erythrophleum africanum. Brachystegia boehmii was the most abundant in both settlement and wildlife zones, with relative sighting frequency of $14 \%$ in settlement zone and $20 \%$ in wildlife zone. Diplorynchus condylocarpon was more abundant in the settlement zone than wildlife zone 9\% and 5\% respectively. The mean and total basal area for all species was higher in the wildlife zone than in the settlement zone, $8420.20 \mathrm{~cm}^{2} ; 117,549 \mathrm{~cm}^{2}$ for wildlife zone and $4346.82 \mathrm{~cm}^{2} ; 30,764 \mathrm{~cm}^{2}$ for settlement zones respectively. Many species had been eliminated from the settlement zone as their sighting frequency was low. Species which had been eliminated in the settlement zone showed low relative sighting frequency of less than $5 \%$ in the wildlife zone. Local communities extended their use of woody plants into the wildlife zone seeking species of preference which had been eliminated in the settlement zone.

\subsection{Building Materials}

Thirty two buildings were surveyed, in which 36 species were recorded as being used in roofing and 25 in walling. Mann-Whitney U test showed a significant difference in the number of species used for roofing and walling $(\mathrm{P}<0.001)$. Woody plant species were selected depending on the human use type and special plant characteristics befitting that human use. Depending on the type and part of building some species were used as roofing poles and others as wall poles while others were used in both walling and roofing. Diplorynchus condylocarpon, Erythrophleum africanum, Parinari curatellifolia, Pericopsis angolensis and Burkea africana were the five most commonly used species for roofing timber. In wall construction, Pericopsis angolensis, Erythrophleum africanum and Burkea africana were the three most commonly used species (Table 1).

\subsection{Pole Size Class Selection in Building Materials}

Among the 32 houses surveyed, girth size and length 
Table 1. Human uses of woody plants in Mumbwa Game Management Area, Zambia, 1998-2011.

\begin{tabular}{|c|c|c|c|c|c|c|}
\hline \multirow{2}{*}{ Species name } & \multicolumn{6}{|c|}{ Human uses } \\
\hline & Firewood & Roof pole & Wall pole & Tools & Fruits/Medicinal & Bee honey/Other \\
\hline Acacia polyacantha & na & $*$ & na & na & na & na \\
\hline Acacia tortilis & na & $*$ & na & na & na & na \\
\hline Afzelia quanzensis & $*$ & na & na & $*$ & na & $*$ \\
\hline Albizia adianthifolia & na & na & na & na & na & $*$ \\
\hline Albizia antunesiana & na & na & na & na & na & $*$ \\
\hline Albizia harveyi & na & na & na & na & na & $*$ \\
\hline Albizia versicolor & na & $*$ & $*$ & na & na & $*$ \\
\hline Anisophyllea boehmii & na & na & na & na & $*$ & na \\
\hline Azanza garckeana & na & na & na & na & $*$ & na \\
\hline Balanites aegyptiaca & na & na & na & na & $*$ & na \\
\hline Bauhinia petersiana & na & $*$ & na & na & na & $*$ \\
\hline Bobgunnia madagascariensis & na & $*$ & $*$ & $*$ & na & $*$ \\
\hline Brachystegia boehmii & $*$ & $*$ & $*$ & na & na & $*$ \\
\hline Brchystegia longifolia & $*$ & $*$ & na & na & na & na \\
\hline Brachystegia manga & $*$ & na & na & $*$ & na & $*$ \\
\hline Brachystegia spiciformis & $*$ & na & na & $*$ & na & $*$ \\
\hline Bridelia micrantha & na & $*$ & $*$ & na & na & na \\
\hline Burkea africana & na & $*$ & $*$ & * & na & $*$ \\
\hline Capassa violacea & na & na & na & na & na & $*$ \\
\hline Combretum collinum & na & na & $*$ & na & na & na \\
\hline Combretum molle & na & na & $*$ & $*$ & na & na \\
\hline Combretum fragrans & na & na & $*$ & na & na & $*$ \\
\hline Combretum imberbe & na & $*$ & $*$ & na & na & na \\
\hline Combretum spp & na & na & $*$ & na & na & na \\
\hline Combretum zeyheri & na & $*$ & $*$ & na & na & na \\
\hline Commiphora mollis & na & $*$ & $*$ & na & na & na \\
\hline Dalbergia melanoxylon & na & $*$ & $*$ & $*$ & na & na \\
\hline Dalbergia nitidula & na & $*$ & $*$ & $*$ & na & na \\
\hline Dalbergia nyasae & na & $*$ & $*$ & na & na & na \\
\hline Dichrostachys cinerea & na & na & na & na & $*$ & na \\
\hline Diospyros kirkii & na & na & na & na & $*$ & $*$ \\
\hline Diospyros mespiliformis & na & na & na & na & $*$ & $*$ \\
\hline Diospyros spp & na & na & na & na & na & $*$ \\
\hline Diplorynchus condylocarpon & na & $*$ & * & na & na & $*$ \\
\hline Ekbergia benguelensis & na & na & na & na & na & * \\
\hline Entada abyssinica & na & na & $*$ & na & na & na \\
\hline Etythrophleum africanus & na & $*$ & $*$ & $*$ & na & $*$ \\
\hline Faurea intermedia & na & na & na & na & na & na \\
\hline Faurea speciosa & $*$ & $*$ & $*$ & na & na & na \\
\hline Flueggea virosa & na & na & na & na & na & $*$ \\
\hline Ficus sur & na & na & na & na & na & $*$ \\
\hline Ficus spp & na & na & na & na & na & $*$ \\
\hline Gardenia spp & na & na & na & na & na & $*$ \\
\hline Hexalobus monopetalus & na & na & na & na & na & $*$ \\
\hline Hymenocardia acida & na & na & na & na & na & $*$ \\
\hline Julbernardia paniculata & $*$ & $*$ & $*$ & na & na & $*$ \\
\hline Julbernardia globiflora & $*$ & na & na & na & na & $*$ \\
\hline
\end{tabular}




\begin{tabular}{|c|c|c|c|c|c|c|}
\hline Kigelia pinnata & na & na & na & na & $*$ & $*$ \\
\hline Lannea discolor & na & na & na & na & na & $*$ \\
\hline Markhamia obtusifolia & na & $*$ & na & na & na & na \\
\hline Monotes africanus & na & $*$ & $*$ & na & na & na \\
\hline Monotes glaber & na & na & na & na & na & $*$ \\
\hline Monotes spp & na & na & na & * & na & na \\
\hline Ochna pulchra & na & $*$ & na & na & na & na \\
\hline Olax obtusifolia & na & na & na & na & na & $*$ \\
\hline Olfiedia dactylophylla & na & na & na & na & na & $*$ \\
\hline Ozoroa insignis & na & na & na & * & na & na \\
\hline Parinari curatellifolia & na & $*$ & $*$ & $*$ & $*$ & na \\
\hline Peltophorum africanum & na & * & na & na & na & na \\
\hline Pericopsis angolensis & $*$ & $*$ & $*$ & * & na & $*$ \\
\hline Pilostigma thonningii & na & na & $*$ & na & $*$ & $*$ \\
\hline Pteleopsis anisoptera & $*$ & $*$ & $*$ & na & na & na \\
\hline Pterocarpus angolensis & na & * & $*$ & * & na & na \\
\hline Pseudolachnostylis maprouneifolia & na & $*$ & $*$ & * & na & na \\
\hline Rauvolfia caffra & na & na & na & na & $*$ & $*$ \\
\hline Rhus longipes & na & na & na & na & $*$ & $*$ \\
\hline Senna abbreviata & na & na & na & na & $*$ & $*$ \\
\hline Sclerocarrya caffra & na & na & na & na & $*$ & na \\
\hline Schrebera trichoclada & na & $*$ & na & na & na & na \\
\hline Staganotaenia araliacea & na & na & na & na & na & $*$ \\
\hline Sterculia quinqueloba & na & na & na & * & na & na \\
\hline Strychnos cocculoides & na & na & na & * & $*$ & na \\
\hline Strychnos inпосиа & na & na & na & na & $*$ & $*$ \\
\hline Strychnos pungens & na & $*$ & na & * & na & $*$ \\
\hline Strychnos spinosa & na & na & na & $*$ & na & $*$ \\
\hline Syzygium cordatum & na & na & na & na & $*$ & $*$ \\
\hline Syzyguim guineense & na & $*$ & $*$ & na & $*$ & na \\
\hline Tamarindus indica & $*$ & na & na & na & $*$ & $*$ \\
\hline Terminalia sericea & na & $*$ & $*$ & na & na & na \\
\hline Terminalia spp & na & na & na & na & na & $*$ \\
\hline Trichilia emetica & na & $*$ & $*$ & * & $*$ & na \\
\hline Uapaca kirkiana & na & $*$ & $*$ & * & $*$ & na \\
\hline Uapaca nitida & na & $*$ & $*$ & na & $*$ & na \\
\hline Uapaca sansibarica & na & na & na & na & $*$ & na \\
\hline Uvariastrum hexaloboides & na & na & na & na & na & $*$ \\
\hline Vitex doniana & na & na & na & $*$ & $*$ & na \\
\hline Ximenia americana & na & na & na & $*$ & $*$ & na \\
\hline Ziziphus abyssinica & na & na & na & na & na & $*$ \\
\hline Zanha africana & na & na & na & na & na & * \\
\hline
\end{tabular}

Notes: Tree species whose uses were not properly defined by the local community were grouped together under other uses. Species which had more than one use or received greater damage were probably most useful to the community.

of poles varied between roofing and walling poles. Roofing poles were longer than walling poles. The average length for roofing poles was 3.5 metres $(n=1856$ poles $)$ and mid length girth was 0.18 metres. The walls consumed shorter but thicker poles than roofs. The average wall pole length was 2.4 metres $(n=896$ poles) and the mid length girth was 0.40 metres. The average number of poles in the roof was 58 and 28 for the wall. The average number of species per roof was 4 and 2 for the wall. Pericopsis angolensis, Burkea africanum and Erythro- 
pleum africanum were commonly used both in roofing and walling units. For these species, relative sighting frequency was below 5\% implying that their numbers were declining.

\subsection{Methods of Collecting Building Poles}

Different methods were used to collect building poles and these were; cutting down the whole tree of desirable size $(60 \%)$, climbing a tree and lopping or pollarding branches of desirable girth and straightness (30\%) and re-using old poles $(10 \%)$.

\subsection{Firewood}

\subsubsection{Pole Size, Species Selected and Transport Used}

As for firewood of the total 60 bundles sampled, the average weight per bundle was $26 \mathrm{~kg}$ and 91 bundles or 2.3 tonnes $(2366 \mathrm{~kg})$ were consumed per head per year. Seven species were particularly selected for firewood. Chi-square test showed a significant difference in the selection of species for firewood $(\mathrm{P}<0.001)$. The reasons given for the selection of species were those yielding good fire with embers lasting a long period of time while producing little smoke. Pericopsis angolensis in particular was chosen because it gave a hot fire and Julbernardia paniculata because it gave hot embers and did not spark (Figure 5). As regards transport, head loads method of fire wood transportation, was the commonest $60 \%$ ), bicycle $27 \%$ and wheel barrow was the least $13 \%$.

Division of labour was based on age group and gender. Women collected most of the firewood $(68 \%, \mathrm{n}=600)$ and of these, female children comprised $31 \%(n=600)$.
This was probably the reason why men seemed generally unconcerned about fuel needs.

\subsubsection{Methods of Collection}

Four common methods of firewood collection were recorded based on 360 respondents:

1) Dead wood collected from the ground. Women and children said that this was an easy method as it did not require cutting down a tree. This method though preferred by women and children was not common $(15 \%)$ because it was difficult to find dead wood in the settlement zone. Late fires usually consumed above ground dry biomass.

2) Standing dead trees are identified and cut down. This was one of the commonest methods (30\%). For hard trees such as Pericopsis angolensis, cutting was done by men, usually the husband or older male children. The mother and children would then return as demand arises to collect branches from the fallen tree. Usually only the branches were removed and large stems were abandoned unless the tree was near the homestead, in which case it would slowly be cut up until finished. Villagers confessed $(83 \%, \mathrm{n}=180)$ entering the restricted wildlife zone or the adjacent National Park in search of dead trees to cut down. One of the respondents whose name could not be revealed for fear of being arrested explained that when they wanted to poach firewood from the National Park, they normally did not cut it using an axe unless it was very far $(>5 \mathrm{~km})$ from a Wildlife Scout's camp as doing so nearby would alert them. Instead they used fire which was left overnight burning, returning the following day to increase the volume of fire if the tree was still standing or to break off branches if the tree had fallen.

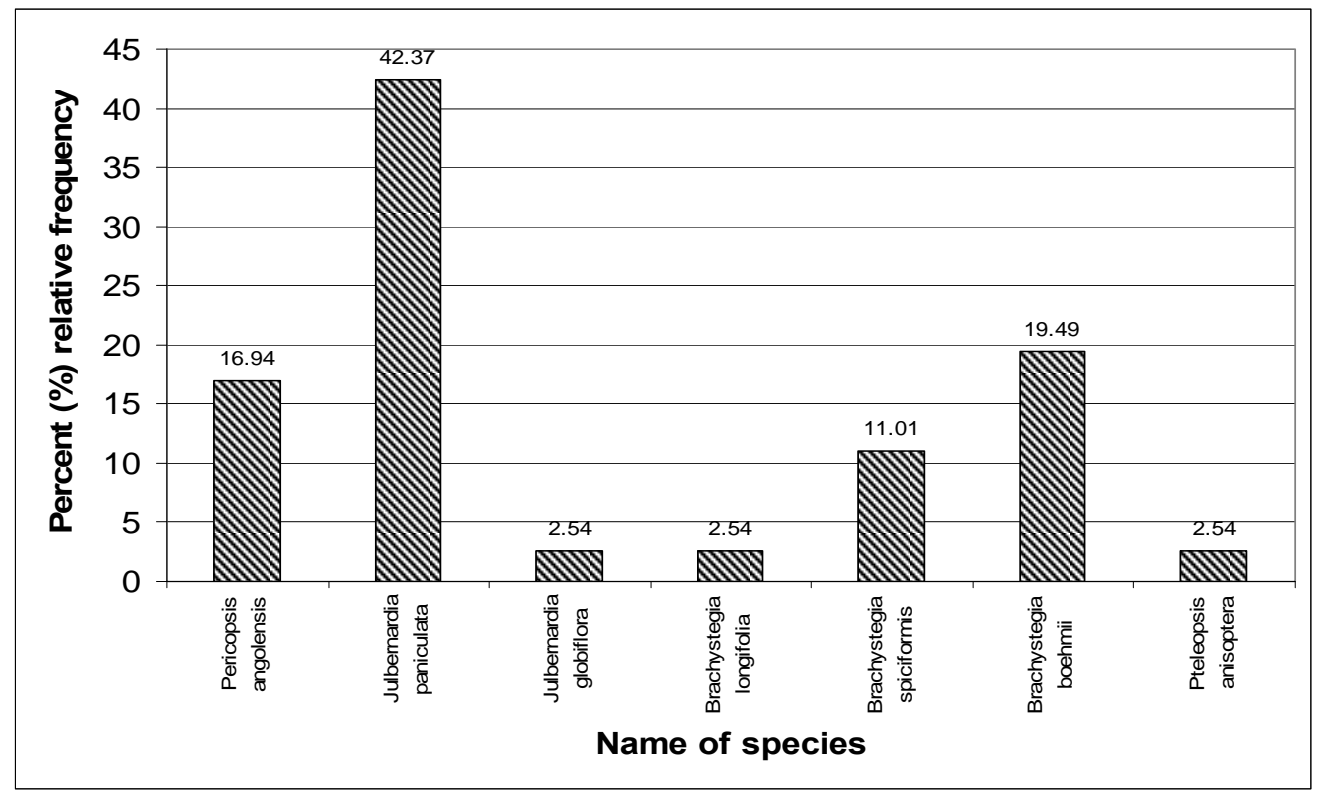

Figure 5. Firewood preferences in the study area, Zambia, 1998-2011/12. 
3) The other method (30\%) was the collection from wood piles. These woodpiles are made when fields are being cleared in readiness for cultivation. In this method there was less species selection as all the woody plants were cleared prior to cultivation. The sizes of poles ranged from saplings with circumference less than $10 \mathrm{~cm}$ (usually used in rekindling a fire) to big stems. If the field was near home, the big logs were slowly reduced to nothing by slicing off with an axe starting with the bark until the whole $\log$ has been taken. This method was most popular during the cultivation period (late OctoberDecember) when households were busy with farm work and little time was available for other activities. It saved a lot of time said one of the female respondents.

4) In this method, a preferred species was felled down and left to dry for many days. Though destructive, it was the second commonest (25\%) method. Firewood collectors, mainly women and children returned to collect as need arose. When a tree has been felled for this purpose then it belonged to that particular household and no other person would knowingly collect the firewood without permission from the rightful owner. This method was highly selective of the most desirable species such as Julbernardia paniculata which was chosen because it can burn and give good embers even before it becomes completely dry.

\subsubsection{Seasonality of Firewood Consumption}

All the respondents in the survey $(100 \%, n=600)$ used firewood for heating, cooking and lighting. All the respondents in the survey $(100 \%, \mathrm{n}=600)$ reported using more firewood in the cold season May-August during which time an average $26 \mathrm{~kg}$ bundle of firewood is consumed in three days time while the same quantity lasted 5 days in the warm season. In the cold season, firewood in addition to cooking was used for heating. This was also the season when maize (Zea mays), sorghum (Sorghum vulgare) and finger millet (Eleusicine coracana) are harvested. Eighty five of the respondents indicated that most wedding parties and rituals that require beer brewing were postponed to this period of the year when food was plentiful. Beer brewing, wedding parties for instance, consume more firewood per unit time than the ordinary day to day usage and bigger logs of circumference usually greater than $50 \mathrm{~cm}$ are used. Single women or widows with school going children reported brewing beer more often as away of raising money for school fees. Some reported to brew up to 200 litres per week. In the rainy season, firewood is piled under shelter of the roof of a kitchen or main house to keep it dry, but one respondent said this way of keeping firewood provides shelter for snakes and would rather have it lean against a big tree so that rain water drains off quickly.

\subsection{Other Uses of Woody Plants}

Honey hunting was a common practice in the local community. Many male respondents $(45 \%, \mathrm{n}=280)$ confirmed having collected honey from bees (Apis mellifera) at least once every year from either wildlife zone or the National Park. The honey collections seasons were; March-May and August-November.

Three common ways of locating bees were recorded. Keeping a look out on trees and the ground for bees; blowing a homemade instrument (usually made from a dry fruit of Strychnos cocculoides). The instrument produced a whistle-like sound which then attracted then greater honey guide (Indicator indicator), and chance encounters of the honey guide as they walk in the bush. It was also found that bees selected host trees and were most popular in five of the recorded species (Table 1).

\subsubsection{Fibre Collection}

Fibre was mainly collected for domestic use. Commercial production of mats and baskets was not recorded. Households engaged in mat making preferred palm leaves.

Fibre was used when collecting firewood to tie it up in bundles. Fibre was not required for big logs as these would be carried by pickup truck, wheel barrow or Scotch-cart. For head loads, strong fibre was needed so that it could not break during transportation. Brachystegia boehmii was the main source of fibre, but when this species was not available other members of the genera $\mathrm{Bra}$ chystegia or Julbernardia were used. Sometimes women recycled old fibre by soaking it in water to make it soft. Saplings of $10 \mathrm{~cm}$ in girth and above were used by either stripping the bark or by felling and debarking. The debarked branches were later picked up as firewood. During fibre collection, strips of $4-5 \mathrm{~cm}$ wide and about 1 $\mathrm{m}$ long were made and thus about $50 \%$ of the circumference of young trees was debarked but sometimes the whole stem was stripped. Fibre for building was collected by men and usually targeted larger trees.

\subsubsection{Medicinal Plants, Wild Fruits and House Hold Items}

1) Medicinal and Magical Value

Most respondents (75\%) were reluctant to reveal medicinal and magical uses of trees. Where names of trees were given, only the disease or condition treated was indicated with no details of how the concoction was prepared and how the treatment was done. Trees recorded for medicinal value are shown in Table 2.

2) Wild Fruits

Many respondents $(67 \%, \mathrm{n}=120)$ indicated that wild fruits were important food items. Thirteen wild edible species were recorded (Table 3). All fruits were collected free of charge from the bush. Anisophyllea boehmii and 
Table 2. Trees of medicinal and magical values recorded in the study area, 1998-2012, Zambia.

\begin{tabular}{|c|c|c|}
\hline Species & Disease treated & Magical value \\
\hline Kigelia africana & & The fruit is used to enlarge male private parts \\
\hline Olax obtusifolia & & Used as a sexual stimulant \\
\hline Piliostigma thonningii & & Bark is used as a lucky charm \\
\hline Combretum zeyheri & Roots are used for treating bilharzia & \\
\hline Rhus longipes & & Charm for attracting women \\
\hline Senna abbreviata & $\begin{array}{l}\text { Root concoction mixed with parts from other } \\
\text { trees is used to treat venereal diseases }\end{array}$ & \\
\hline Diplorhynchus condylocarpon & Roots and leaves are used to treat snake bites & \\
\hline Balanites aegyptiaca & Kills bilharzia snails & $\begin{array}{l}\text { Root concoctions mixed with animal parts especially warthog } \\
\text { tail, is used as a sexual stimulant and also cures male impotence }\end{array}$ \\
\hline Rauvolfia caffra & & Used to repel visiting witches \\
\hline Oldfieldia dactylophylla & Root concoctions used to treat venereal diseases & \\
\hline Dalbergia nitidula & Used to treat venereal diseases and pneumonia & \\
\hline Ekbergia banguelensis & $\begin{array}{l}\text { Root concoctions are used to promote female } \\
\text { fertility and also cures gonorrhea }\end{array}$ & \\
\hline Sclerocarya caffra & & $\begin{array}{l}\text { Used to regulate sex of the child to be born as required } \\
\text { by the couple }\end{array}$ \\
\hline
\end{tabular}

Table 3. Indigenous fruit trees and nutrient composition of some selected species in the study area, 1998-2011, Zambia.

\begin{tabular}{|c|c|c|c|c|c|c|c|c|}
\hline \multirow{2}{*}{ Species } & \multirow{2}{*}{ Popularity } & \multirow{2}{*}{ Sold } & \multicolumn{6}{|c|}{ Nutritional value } \\
\hline & & & Energy (KJ) & Energy (Cal.) & Water $(\mathrm{g})$ & Prot. (g) & Fats (g) & $\mathrm{Ca}(\mathrm{g})$ \\
\hline Anisophyllea boehmii & ** & + & 1345 & 322 & 74 & 0.60 & 1.0 & 45.0 \\
\hline Azanza garckeana & $*$ & + & & & & & & \\
\hline \multicolumn{9}{|l|}{ Diospyros mespiliformis } \\
\hline Parinari curatellifolia & * & + & 1474 & 353 & 70.8 & 2.5 & 0.3 & \\
\hline Strychnos cocculoides & * & + & 1382 & 331 & 76 & 0.3 & 0.3 & 45.0 \\
\hline \multicolumn{9}{|l|}{ Strychnos innocua } \\
\hline Syzygium guineense & & & 1407 & 337 & 80 & 5.9 & 5.5 & 600.0 \\
\hline \multicolumn{9}{|l|}{ Tamarindus indica } \\
\hline Uapaca kirkiana & ** & + & 1420 & 340 & 58 & 0.2 & 1.0 & 40.0 \\
\hline \multicolumn{9}{|l|}{ Uapaca nitida } \\
\hline \multicolumn{9}{|l|}{ Uapaca sansibarica } \\
\hline Ximenia americana & & & & & & & & \\
\hline
\end{tabular}

Key: En. KJ = Energy in kilojoules, En. Cal = Energy in kilocalories, Prot. = Protein; ${ }^{*}$ Popular, ${ }^{* *}$ very popular, + sold.

Uapaca kirkiana were the most popular. Parinari curatellifolia, Anisophyllea boehmii and Uapaca kirkiana were occasionally sold at the road side. However, half of the respondents $(50 \%, \mathrm{n}=120)$ indicated that the evergrowing preference for exotic fruits like orange (Citrus spp), mango (Mangifera indica) and others relegates wild fruits to poor families or for using during periods of drought. Fruit trees however, were preserved in all farm plots, around homes for shade and food.

3) Household Items, Species Used and Replacement Period
Eight house hold items were recorded to have made from woody plants. There were a strong species selection for most tools and utensils. These were; mortar, pestle, cooking stick, axe handle, hoe handle, canoe making, stool and drums of various size (Table 4). The durability of the tree species used and/or the treatment made during the preparation and curative process of the item determined the replacement period. Tools that were made from strong species and that were treated by for instance passing through a fire or soaking in water for a given length of time lasted longer than those that did not re- 
Table 4. Household items, woody plant species used and replacement period in years, 1998-2012, Zambia.

\begin{tabular}{|c|c|c|}
\hline $\begin{array}{c}\text { Name of } \\
\text { household tool } \\
\text { or utensil }\end{array}$ & Tree species used & $\begin{array}{l}\text { Replacement } \\
\text { period in years }\end{array}$ \\
\hline \multirow[t]{4}{*}{ Motar } & Albizia antunesiana & 20 \\
\hline & Pterocarpus angolensis & 20 \\
\hline & Terminalia spp & 20 \\
\hline & Parinari curatelifolia & 20 \\
\hline \multirow[t]{6}{*}{ Pestle } & Monotes spp & 18 \\
\hline & Burkea africana & 20 \\
\hline & Bobgunnia madagascariensis & 20 \\
\hline & Terminalia spp & 18 \\
\hline & Albizia antunesiana & 15 \\
\hline & Pericopsis angolensis & 20 \\
\hline \multirow[t]{6}{*}{ Cooking stick } & Strychnos cocculoides & 5 \\
\hline & Uapaca kirkiana & 8 \\
\hline & Ximenia Americana & 5 \\
\hline & Ozoroa reticulata & 8 \\
\hline & Pterocarpus angolensis & 8 \\
\hline & Faurea speciosa & 7 \\
\hline \multirow[t]{5}{*}{ Axe handle } & Brachystegia spiciformis & 2 \\
\hline & Dalbergia nitidula & 5 \\
\hline & Julbernardia globiflora & 2 \\
\hline & Bobgunnia madagascariensis & 5 \\
\hline & Pterocarpus angolensis & 5 \\
\hline \multirow[t]{5}{*}{ Hoe handle } & Julbernardia globiflora & 2 \\
\hline & Brachystegia spiciformis & 4 \\
\hline & Pterocarpus angolensis & 4 \\
\hline & Bobgunnia madagascariensis & 4 \\
\hline & Albizia antunesiana & 5 \\
\hline Canoe & Afzelia quanzensis & 3 \\
\hline \multirow[t]{3}{*}{ Stools } & Albizia antunesiana & $>20$ \\
\hline & Afzelia quanzensis & $>20$ \\
\hline & Brachystegia spp & $>20$ \\
\hline \multirow[t]{2}{*}{ Drums } & Albizia antunesiana & $>20$ \\
\hline & Sterculia quinqueloba & $>20$ \\
\hline
\end{tabular}

ceive any treatment. The species of the tree used and the treatment used were found to be the most important factors determining the replacement period. This did not however, discount the extent and frequency of use which would also reduce the replacement period.

\subsection{Incidences of Cut Categories}

Cut categories 1 - 3 which involved cutting of the stem or branch were combined to make one category and cut categories 4 - 5 which do not involve cutting of stem or branch formed another category. A significant difference was found between the two classes, with category 4 and 5 being the commonest. Comparison of the five categories showed that stripping was the commonest form of damage Mann-Whitney U test $0.02<\mathrm{P}<0.05$ (Figure 6).

\section{DISCUSSION}

\subsection{Use of Woody Plants}

Local communities in Mumbwa GMA utilize woody plant species in many ways to provide for their subsistence. The study proved that despite lower species diversity in miombo woodlands compared with tropical rain forests, the miombo woodland species probably provide more useful types per species than the tropical rainforest species [31]. In their study of the ethno botany in Amazonian Terra-Firme rain forest, found between 34 and 76 tree species which were useful in at least one way or another per hectare plot which was between $49 \%$ and $79 \%$ of all species present. In this study conducted in a miombo woodland, 92 (99\%) of the 93 species recorded were used by local communities and many of the species had more than one human use per tree species.

Other studies on miombo woodlands in central Zambia indicate that most of the research works on vegetation and use has often over emphasized the great diversity of tropical rain forests [38]. Yet the miombo woodlands provide a great diversity of uses even if the number of species per unit area may be less than the tropical rain forest.

\subsection{Differences in Plant Density between Settlement and Wildlife Zone}

Of the 93 species recorded during the study, 64 were recorded in the wildlife zone and 39 in the settlement zone. The differences in species diversity are attributed to clearing for agriculture in the settlement zone. Other uses such as collection of building poles and firewood may also selectively eliminate some species which cannot tolerate the impact. Clearing for agriculture for instance, involves uprooting trees and subsequent suppression of regeneration during cultivation. Some species however, such as Bracystegia boehmii and Diplorynchus condylocarpon are still common in the settlement zone probably because of the high regeneration potential and fire tolerance for the latter.

It is also important to note that species that provide more than one use where for instance, the roots, bark, stem and leaves are useful are likely to disappear earlier than those with fewer uses. Form the results of this study, it would appear that when preferred species are eliminated in the settlement zone, rather than turning to alternatives or planting fast growing exotic species, villagers 


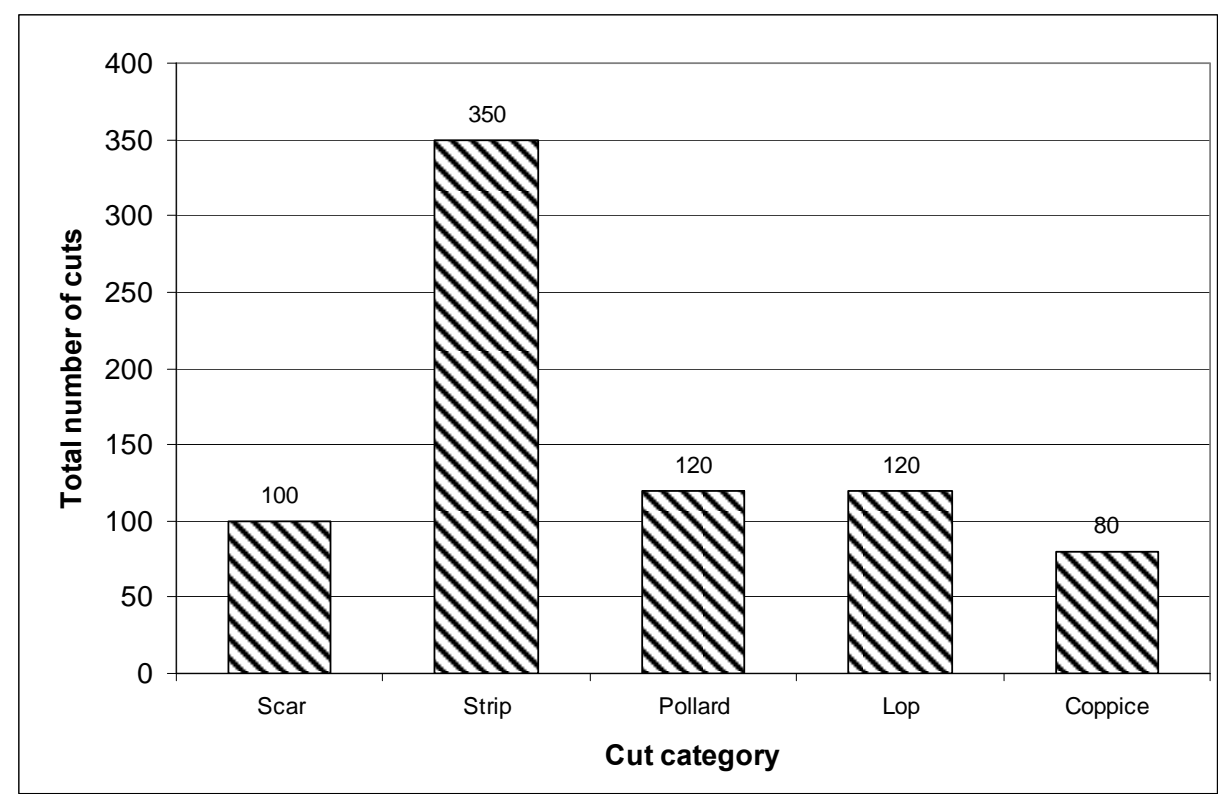

Figure 6. Comparisons of cut categories; coppicing, pollarding, lopping, stripping and scarring in the study area, 1998-2012, Zambia.

chose to collect from the wildlife zone and National Park. This trend is expected to increase as settlements expand. The declining sighting frequency of some species in the settlement zone is an indication that they are being sought after for their particular characteristics. After exploring different ways in which woodland resources are utilized, $[8,32,33]$ showed that it was apparent that the increasing scarcity of miombo woodland resources in settled areas is largely a function of clearance of woody species for cultivation. This study also proves this fact.

In Mumbwa GMA, considerable tenural conflicts arise because rural household believe they have the right to use the land and the resources by virtue of proximity or historical connection to the land often leading to people extending their settlements into the wildlife zone where they access virgin land for agriculture and game meat for protein. Respondents 35 years and older especially women showed great attachment to the resources of the area. Such conflicts are also experienced in other countries in the southern African sub region. In Malawi, for example, $[8,32]$ reported encroachment by smallholders on state lands for poles, firewood, thatch, grazing and even cultivation. The frequency of such cultivation suggests that the creation of estates has restricted small holders' access to forest and other resources as well as access to arable land needed to meet their food requirements. In fact National Forestry Policies are directed towards limiting commercial exploitation of woodlands. The focus is on regulating woodland use and protection against wanton cutting of trees and encroachment rather than on sustainable utilization and management.

These limitations are extended to woodlands nontradi- tional lands through control regimes, licensing, traffic check points, roadblocks and increased royalty collection from users of woodlands. This means that rural households have no right to exploit trees growing on their land except to cut them when clearing for agriculture $[8,34$, 35]. There is also a tendency by foresters to consider local communities' use of woodland for non commercial purposes a major cause of deforestation when in actual fact many human uses unless commercialized, do not have deleterious effects on regeneration of miombo woodlands. It was further documented that the dominant trend in regenerating miombo woodland in the absence of frequent hot fires or other intense disturbances is towards woodland $[14,36]$. Unless plants have been thoroughly uprooted during the initial disturbance, most of the subsequent development of woodland derives from re-growth of coppice from surviving stems and rootstocks. However, he also noted that marked changes in composition and very slow if any, recovery to the original state is likely in areas where Brachystegia, Julbernardia and other Caesalpiniodeae have been eradicated because these trees have extremely low ability for seed dispersal and their seeds are short lived. It is not easy, however, to eradicate these species anyway. In this survey, contrary to the general perception that all human uses of woody plants cause deforestation, the most destructive was clearing for agriculture. Other human uses that were found to be destructive was the uprooting of Rhynchosia insignis (Munkoyo roots), which are used in the preparation of a local beer called "Munkoyo" which has led to local extermination of this species in the GMA. 
The other destructive human use of woody plants which was revealed during the survey was the debarking of trees for making beehives. One of the popular species for bark bee hives is Julbernardia paniculata. Debarking kills trees but the frequency of debarking is not known. Whatever the frequency when trees die after debarking, small gaps are created in the forest, such gaps are beneficial to the regeneration of valuable timber species such as Pterocarpus angolensis, so the extent to which this practice of killing trees by debarking may be destructive or beneficial requires to be investigated [37]. What this study gathered was that honey hunting activities are accompanied by debarking of trees for containers to carry honey, but this does not often involve debarking, although debarked patches are later burnt by fires making the tree hollow and reducing their value for timber [8].

Commercial charcoal production through not covered by this study can also lead to woodland depletion as deforestation tends to be rather intensive due to wide ranging search for suitable species [8,38]. Human use and resource depletion has also become a factor in the production of fine hardwoods. In Tanzania use of indigenous timber was declining along with supply [39]. In Zimbabwe, the share of indigenous woods from domestic sources in overall industrial wood supply fell from $534,600 \mathrm{~m}^{3}$ to $108,500 \mathrm{~m}^{3}$ between 1975 and 1990. This decline in the production of fine hardwoods reflected growing depletion of the stocks. In Tanzania, production in sawmills processing indigenous hardwoods dropped well below capacity in part due to depletion of wood resources in the vicinity of the mills [39].

\subsection{Species and Size Class Selection for Building Poles}

Poles, especially for house construction, were widely used as rafters covered in grass thatch of for walls coated with clay. More than $80 \%$ of the community in 1998 used poles with mud for walls and thatch for roofing. This number had declined to $50 \%$ in 2011 . House building is not done annually except for new arrivals but repairs and extensions especially of granaries are done annually $(89 \%, n=600)$. Larger poles were needed for centre or corner posts or where additional strength was required. If the building was for public use such as a church or mosque, the roofing poles were longer than a private dwelling house. Wall poles took fewer but thicker poles than roofing poles. This was because the wall carries much of the weight of the building and requirements of desirable characteristics such as durability as in resistance to insect attack and rotting as well as straightness were critical. Rather than collect every species in equal quantities, communities select species because of their characteristics and labour costs involved. When species of desirable characteristics are lacking, in the settlement zone, communities will disregard the rules restricting the cutting of trees in wildlife zone and National Park which indicates lack of legitimacy of the tenure systems in the eyes of the local people.

In general, the collection of building poles was not destructive to the woodland unless commercialized. This is because people were selective in their uses often going for durable and insect and moisture resistant species which prolong the replacement cycle after which considerable coppicing and regeneration would have taken place. When they return to harvest at a later time, they again select species and size classes according to human use type leaving others to grow. Additionally, each human use selects different species, a tree taken for firewood may sometimes be different from building pole and the same goes for girth size. However, it is argued that factors other than direct collection of plants affect abundance $[8,40]$. Increased disturbance would generally decrease diversity, yet it would increase abundance of those species which thrive in disturbed environments. Diplorynchus condylocarpon for instance which is fire tolerant thrives in areas burnt annually like in the settlement zone. However, he cautioned that human uses that target saplings and young trees should be closely monitored because these harvesting methods when combined with late fires may surprises regeneration, or for the latter, cause holes in trees and repeated fire resulting in death of the tree [41].

\subsection{Methods of Collecting Building Poles}

Regarding harvesting methods, the height at which a tree is cut is important because it affects the nature and rate of regeneration. The higher the tree is cut the less the biomass that is removed and the tree is likely to recover quickly $[8,41,42]$. Pollarding and lopping can be applied in harvesting fuel wood, building poles or obtaining fibre rather than felling the whole tree. Lopped trees regenerate faster producing greater biomass over shorter periods of time than trees cut close to the ground [8]. In fact selective branch removal could yield wood and leaf products with much less disturbance to the overall woodland than the removal of the whole tree [8]. In clearing for agriculture, trees were either stumped or cut at breast or waist height. In this case re-growth stems or branches are invariably defective at the point of cutting. Consequently the pole and timber value of re-growth is low [7,8,40,43]. Cutting trees at waist/breast height are not suitable techniques for regeneration. In cutting trees for fuel wood, poles and timber the cutting is usually done close to the ground. In such cases woodland regeneration is mainly by root coppice. If fire does not damage the regeneration, straight poles are produced [11,41]. Selective thinning can be practiced to provide building poles in short term and in the long term saw logs. It was suggested that trees 
should be felled at $15 \mathrm{~cm}$ above ground and at an angle of $45^{\circ}$ using a sharp axe or saw to encourage vigorous regrowth from the stump $[11,41,44]$. Deep ploughing on the other hand would increase the stocking rate by causing root suckers to develop but only when the fallow period is long $[44,45]$.

\subsection{Firewood}

Results showed that seven species were most popular species for firewood. The reason for their preference is due to their particular properties rather thjan abundance. The species chosen give good embers, hot fire, and burn easily producing little smoke. The species selection may continue for some in the future for as long as sources are nearby. However, as population increases and commercial charcoal production increases there would be need for intervention.

\subsubsection{Areas of Intervention in the Fuel Wood Cycle}

The starting point in tackling the fuel wood problem must be the multiple roles that trees perform in the environment within which people live and work. Starting by establishing people's needs, energy planners can then go on to look at what trees would be suitable for particular areas and how long they take to grow. These decisions enable the woody biomass production system to be developed and managed. By understanding and incorporating the knowledge of the people, they can make available a rich tool kit for the management of the woody biomass and explore new avenues for research and development programmes led by the needs of the people.

Simply getting trees into the ground may not slow deforestation or solve local fuel problems. Building on local traditional knowledge about uses of trees would be the most effective way of stimulating new tree growing initiatives. Where people do not generally plant trees as in the study area, management of coppicing would ensure a steady supply. The strong traditions on coppicing recorded in this study can be used to improve harvesting. Both coppicing and pollarding can be effective methods of obtaining a sustained yield of small diameter wood from stands of trees over long period of time.

\subsubsection{Fuel Wood Consumption}

Regarding firewood consumption per head per year, results from other parts of the world reveal similar trends as the ones observed in the study area. For example, a survey of 518 small farm families in different parts of Nicaragua where most cooked with fuel wood, showed that consumption ranged between $1100 \mathrm{~kg}-2865 \mathrm{~kg}$ per person per year. In north eastern Tanzania, in Kwemzitu village, which is near a forest reserve from which people are allowed to collect fuel wood, the annual consumption was found to be in the range of $1636 \mathrm{~kg}-2605 \mathrm{~kg}$ per head per year. The $2366 \mathrm{~kg}$ consumption per head per year obtained in this study is therefore in the average upper range an indication that fuel wood is not yet a limiting factor for households in this area.

Availability of fuel wood was a key determinant factor of how people use it [8]. In areas where it is plentiful, people may use as much as $2000 \mathrm{~kg}$ per head per year or more. Where scarcity has forced to switch to fuels such as straw and animal dung, fuel wood consumption may drop to zero. In villages in Lesotho and South Africa's Transkei, where wood is scarce, the annual per capita fuel wood consumption was $288 \mathrm{~kg}$ and $271 \mathrm{~kg}$ supplemented $271 \mathrm{~kg}$ and $260 \mathrm{~kg}$ of crop residue and dung respectively. But in a village in Kwazulu in South Africa where wood was abundant, consumption was $1124 \mathrm{~kg}$ per head per year. In areas where wood is scarcer, consumption is lower. Survey of six villages in Mali and Niger found people using only $440 \mathrm{~kg}-660 \mathrm{~kg}$ per head per year. Similar consumption patterns were recorded in from a survey of 17 villages in Tamil Nadu, India where a range of $344-676 \mathrm{~kg}$ per head per year with an average of $481 \mathrm{~kg}$ was recorded by [8]. In five other villages of Orissa, India, consumption ranged from $509-826 \mathrm{~kg}$ per head averaging $680 \mathrm{~kg}$.

Family size also influenced per capita fuel requirements. Larger families cooking bigger meals can be much more efficient in their use of fuel wood. In one village in Nepal, families with between 1 - 4 members used an average of $890 \mathrm{~kg}$ of firewood per person each year. Families with 9 members or more used less than half this amount per person, about $340 \mathrm{~kg}$. Based on the above experiences it was assumed that the average family size of 9.4 (minimum $=1$, maximum $=23$, mean $=$ 9.4, $\mathrm{SE}=4.4$ ) in the study area, which is on the larger size, it is likely that fuel wood usage would be economical, but again this depends on whether firewood is commercialized or not [8].

\subsubsection{Seasonal Use of Firewood}

The second consumption of wood is dictated by weather. In the study area, an average $26 \mathrm{~kg}$ bundle of firewood was consumed in three days time in cold weather and five days in warm weather. Cold weather also coincided with harvesting of crops and this was also the time when many traditional rituals that require beer brewing and also weeding parties are done at this time which collectively increases firewood consumption. For as long as these traditional rituals do not attract outside interests the fire wood demand is unlikely to outstrip supply.

\subsection{Bee Honey Collection}

Bee honey hunters usually debark trees usually Brachystegia or Julbernardia to make a container for carry- 
ing honey home. To what extent this would be damaging to woody plants needs to be examined. There are however, some alternatives particularly when the community is encouraged to start bee keeping schemes. Calabashes, damaged clay pots, and bee hives made from exotic timber and many others can be used, hence the frequency of debarking is likely to be low. Currently the collection method is such that when a bee colony is located, especially if it is above average human height, a forked ladder is used is made to enable the collector reach the hive or the tree is felled down. A fire is made and quite often old pieces of cloth, old tyres are burnt to lessen stinging. If the tree is not cut down a hole is made in the tree. After collecting the honey, honey hunters rarely extinguish the fire. During the August-November honey collection season, honey collectors were major causes of wild fires as reported by $20 \%(n=180)$ respondents that honey collection caused about $80 \%$ of fire incidences. This figure could not be verified as fires from fields as they being cleared in readiness for cultivation were also another major source. Honey collection therefore, as a type of human use of woody plants is damaging to large trees while fires left behind may cause damage to saplings and regenerating plants.

\subsection{Fibre}

Results of the PRA showed that firewood collectors often re-used the old fibre by soaking it in water to soften it. The frequency with which new fibre is collected is likely to be low. Other means of fire wood transportation such as by wheelbarrow do not require tying firewood in bundles. Fibre used in construction and basket/mat making on the other hand, is treated in black clay soil to strengthen it. By doing so, its life span is increased and therefore the replacement period is often long. Although data was not collected about quantities of fibre collected, it was assumed that the overall demand for new fibre is generally low [8].

\subsection{Household Items, Tools, Species Used and Replacement Period}

Utensils and tools are of immense value to the rural communities' daily lives and agricultural work; pounding food, firewood and building poles collection, all depend on locally made tools and utensils derived from wood.

In the study area, many households are made from woody plants. It was difficult in certain circumstances to take accurate girth measurements of the tree species from which the tool came from because most of them involve complete modification of the natural shape. On the whole, utensils represent low level exploitation because of the species selection and replacement cycles. Some tool making methods are however, destructive. For example, axe handles require that the tree be uprooted to make use of the bulge at the base of the tree which has crossed grains to withstand the cutting impact, but again it is only destructive when commercialized as the replacement cycle for axe handles is approximately four years. Other items such as the motar or drums use larger trees of girth greater than $100 \mathrm{~cm}$ to allow for carving out a hollow, while a pestle only requires debarking and smoothening the ends, but these have a long replacement cycle of over 20 years.

\subsection{Fruits}

Indigenous fruits may not look as appetizing as exotics, but are often nutritious and healthier due to increasing use of insecticides and growth promoters in exotic species. Apart from yielding fruit for human consumption, they are also a source of income to small holders [46-49]. The extent to which indigenous fruit is marketed was not covered in this survey, but in other studies $[48,49]$ it was noted that marketing depended on availability, shelf life, demand patterns and access to market, sale price and effectiveness of social controls regulating the sale of these products. Quite often the availability of exotic fruits such as mango takes precedence over indigenous fruits. Low indigenous sales, as low as $1 \%$, but high sales of up to $56 \%$ for exotic fruits have been recorded in Zimbabwe [46-49] recorded very low. Although we did not gather information on income from wild fruits in this study, income from the sale of wild fruits is expected to contribute significantly to women's and children's income. This was based on the fact that most of the trees conserved in the fields were fruit trees. These observations also agree with those obtained in Mutoko Communal Area in Zimbabwe where most of the indigenous trees conserved in home fields were edible fruit bearing species [49]. It was also noted two indigenous trees Ziziphus mucronata and Uapaca kirkiana, both of which are edible, being planted by villagers [49].

\subsection{Suggested Future Research Needs}

The area of sustainable use of woody plants is an area of particular interest as local communities undergo rapid social, economic and political change. The transaction of establishing and centralizing institutional mechanisms for local resource management may be high to the point where institutions such as Forestry Department and Zambia Wildlife Authority may only be able to maintain high value and quick return resources such as game animals. In light of the above, we suggest future research activities as follows:

1) Examine the chances for local management can utilize low value resources such as woody plant resources on a sustained yield basis. 
2) Identify simple and practicable mechanisms for strengthening local institutions and to develop methodologies to assess the comparative value of woodland resources especially in relation to other land uses.

3) Examine institutional mechanisms which ensure that local communities have control over resources of their landscape in the face of possible appropriation by outside elite groups.

4) Examine how scientific/ecological recommendations of using fire, coppicing and others can be feasibly be used as tools by local people to manage woodlands on traditional land.

5) Policy development that empowers local people to manage woodlands in their traditional landscape where law permits.

6) Investigates how empowerment would best be achieved, for what products and in what circumstances; so far the Community Based Natural Resources Management programmes may not be wholly applied to woodland products because of their low value compared to game animals; devolution per se is no panacea to sustainable use but it may be crucial first step, which needs to be investigated in detail by future research.

7) As for the ability for the woodland to coppice after human use, it is at the moment not clear whether the ability to produce coppice shoots and stump survival rate is correlated with girth size or age; it is important that future research activities thoroughly address this question.

8) The other topic of importance is that while attractive in theory, indigenous forest management faces serious technical challenges; little is known about feasible rotation patterns and how best to incorporate controlled grazing and wood cutting into indigenous forest management.

9) Develop a simple monitoring system for assessing human related threats to the ecology of the area.

10) Develop a mechanism for relating the extent of such threats to human related factors of society, population pressure, socio-economic standing, source of livelihood, contemporary and traditional law enforcement structures and mechanisms, incentives, environmental awareness and politics.

11) Develop a mechanism for using such information for planning and management as they relate to developing the potential of sustainable use of renewable woody plant resources.

12) In this survey, we excluded woody plants of dbh of less than $10 \mathrm{~cm}$; this was a weakness as has been the case with other similar vegetation studies, as this implies excluding plants in the pre-sapling phase, which probably form a large reservoir for future trees; future research should consider saplings and that shoot growth among suppressed saplings is low while these plants accumulate a relatively large below ground biomass constituting perennating tissue that regenerates new shoots following repeated shoot die back in the dry season.

\section{ACKNOWLEDGEMENTS}

Field assistants L. Mboote, L. Musa (late), P. Shamalundu, C. Malisawa, R. Chisangu, W. Sakala and M. Cheleka conducted vegetation surveys and identified tree species encountered and also assisted in the translation of names from vernacular to botanical names particularly for species used in tool making and implements. Enumerators; Jane Shimwense, Veronica Muyanda, Wambulwawaye Mubita and Joyce Mwenda Namukombo were excellent in questionnaire surveys. We highly appreciate the field skills which made this project a success.

\section{REFERENCES}

[1] Campbell, B., Frost, P. and Byron, N. (1996) Miombo woodlands and their use: Overview and key issues. In: Campbell, B.N., Ed., The Miombo in Transition: Woodlands and Welfare in Africa, Centre for International Forestry Research, Bogor, 1-5.

[2] Campbell, B. and Byron, N. (1996) Miombo woodlands and rural livelihoods: Overview and key issues. In: Campbell, B.N., Ed., The Miombo in Transition: Woodlands and Welfare in Africa, Centre for International Forestry Research, Bogor, 221-263.

[3] Clarke, J., Cavendish, W. and Coote, C. (1996) Rural households and miombo woodlands, use value and management. In: Campbell, B.N., Ed., The Miombo in Transition: Woodlands and Welfare in Africa, Centre for International Forestry Research, Bogor, 101-135.

[4] Bradley, P.N. and Dewees, P.A. (1993) Indigenous woodlands, agricultural production and household economy in communal areas. In: Bradley, P.N. and McNamara, Eds., Living with Trees: Policies for Forestry Management in Zimbabwe, World Bank Technical Paper 210, World Bank, Washington, 63-157.

[5] Fischer, F.U. (1993) Bee-keeping in the subsistence economy of the miombo savannah woodlands of south central Africa. Rural Development Forestry Network Paper, Overseas Development Institute, London, 1-2.

[6] Birchenoughl, L. (1993) The impact of natural resource utlisation on miombo woodland in Zambia. Unpublished MSc. Thesis University College of London, 1-96.

[7] Hosier, R.H. (1993) Charcoal production and environmental degradation. Energy Policy, 21, 491-505. http://dx.doi.org/10.1016/0301-4215(93)90037-G

[8] Chansa, W. (2000) Utilisation of woody plant species by local communities in Mumbwa Game Management Areas, Zambia. Unpublished MSc. Thesis, University of Zimbabwe, Harare, 1-99.

[9] Nahonyo, C.L., Mwasumbi, I. and Bayona, D.G. (1998) Survey of the vegetation communities and distribution of woody plant species in Mbomipa Project area. Report No. 1 MCRI Iringa, 1-81.

[10] Dove, M. (1993) A revisionist view of tropical deforesta- 
tion and development. Environmental Conservation, 20, 17-25. http://dx.doi.org/10.1017/S0376892900037188

[11] Chidumayo, E.N. (1987) Woodland structure, destruction and conservation in the Copperbelt areas of Zambia. Biological Conservation, 40, 89-100. http://dx.doi.org/10.1016/0006-3207(87)90060-7

[12] Chidumayo, E.N. (1989) A land use, deforestation and reforestation in the Zambian Copperbelt. Land Rehabilitation, 1, 209-216.

[13] Price, L. (1998) Farmers do conserve and plant trees in communal areas: A case study in Mutoko communal area. The Zimbabwe Science News, 32, 4-6.

[14] Hoffman, M.T. and Cowling, R.M. (1980) Vegetation changes in semi arid and eastern Karoo over the last two hundred years: An expanding Karoo? South African Journal of Science, 118, 286-294.

[15] Burley, J. (1979) Choice of tree species and possibility for genetic improvement for small holder and community forests. Commonwealth Forestry Review, 59, 3-7.

[16] Clarke, C. and William, C. (1976) Maintenance of agriculture and human habitats within Tropical Forest Ecosystems. Human Ecology, 4, 217-259. http://dx.doi.org/10.1007/BF01534289

[17] Lusigi, W.J. (1981) New approaches to wildlife conservation in Kenya. Ambio, 10, 2-3.

[18] Mackinnon, J., Mackinnon, K., Child, G. and Thorsell, J. (1986) Managing protected areas in the tropics. The World Conservation Union (IUCN), Gland, 99-117.

[19] Ehrlich, R. and Paul, R. (1982) Human carrying capacity, extinction and nature reserve. Biosc, 32, 321-326.

[20] Nhira, C. and Fortman, L. (1993). Local woodland management: realities of the grass roots. In: Bradley, P.N. and McNamara, Eds., Living with Trees: Policies for Forestry Management in Zimbabwe, World Bank Technical Paper 210, World Bank, Washington DC, 139-156.

[21] Cunningham, A.B. (1990) The regional distribution, marketing and economic value of the palm wine trade in Ingwavuma District. South African Journal of Botany, 56, 191-198.

[22] Cunningham, A.B. (1991) Development of a conservation policy on commercially exploited medicinal plants: A case study from southern Africa. In: Akerele, Heywood and Synge, Eds., Conservation of Medicinal Plants, Cambridge University Press, 337-358.

[23] Talukdar, S. (1993) The conservation of Aloe polyphylla endemic to Lesotho. Bothaia, 14, 985-989.

[24] Lawton, R.M. (1978) A study of the dynamic ecology of Zambian vegetation. Journal of Ecology, 66, 175-198. http://dx.doi.org/10.2307/2259187

[25] Trapnell, C.G. (1959) Ecological results of woodland burning experiments in Northern Rhodesia. Journal of Ecology, 47, 129-168. http://dx.doi.org/10.2307/2257252

[26] Fanshawe, D.B. (1972) Useful trees of Zambia for the agriculturalist. Ministry of Lands and Natural Resources. Government Printer, Lusaka, 3-127.

[27] Cole, M.M. (1963) Vegetation and geomorphology in Northern Rhodesia: An aspect of the distribution of the savannah of central Africa. Geology Journal, 129, 290305.

[28] Stohlgren, T.J., Falker, M.B. and Schell, L.D. (1995) A modified Whittaker nested vegetation sampling method. Vegetatio, 117, 113-121. http://dx.doi.org/10.1007/BF00045503

[29] Mueller-Dumbois, D. and Ellenberg, H. (1974) Aims and methods of vegetation ecology. John Wiley and Sons, London, 45-58.

[30] Walker, B.H. (1970) An evaluation of eight methods of botanical analysis in Rhodesia. Journal of Applied Ecology, 7, 3-12. http://dx.doi.org/10.2307/2401967

[31] Prance, G.T., Balee, W., Boom, B.M. and Carneiro, R.L. (1987) Quantitative ethnobotany and the case for conservation in Amazonia. Conservation Biology, 1, 4-10. http://dx.doi.org/10.1111/j.1523-1739.1987.tb00050.x

[32] Johns, A.D. (1981) The effects of selective logging on the social structure of resident primates. Malaysian Applied Biology, 10, 221-226.

[33] Keith, G. (1984) The relationship between adjacent land and protected areas: Issues of concern for the protected area manager. In McNeely and Miller, Eds., National Parks, Conservation and Development: The role of Protected Areas in Sustaining Society, Smithsonian Institution Press, Washington DC, 65-71.

[34] Lewis, D., Kaweche, G.B. and Mwenya, A.N. (1990) Wildlife conservation outside protected areas, lessons from an experiment in Zambia. Conservation Biology, 4, 171-180.

http://dx.doi.org/10.1111/j.1523-1739.1990.tb00106.x

[35] Frost, P. (1996) The ecology of miombo woodlands. In Campbell, Ed., Miombo in Transition: Woodlands and Welfare in Africa, Centre for International Forestry Research, Bogor, 11-55.

[36] Lawton, R.M. (1982) Natural resources of the miombo woodlands and recent changes in agricultural land use practices. Ambio, 14, 362-365.

[37] Dove, M. (1993) A revisionist view of tropical deforestation and development. Environmental Conservation, 20, 17-25. http://dx.doi.org/10.1017/S0376892900037188

[38] Monela, G.C., O'Kting'ati, A. and Kiwele, P.M. (1993) Socio-economic aspects of charcoal consumption and environmental consequences along the Dar es SalaamMorogoro highway. Forest Ecology and Management, 58, 249-258. http://dx.doi.org/10.1016/0378-1127(93)90148-G

[39] Kowero, G.S. and Temu, A.B. (1985) Some observations on implementing village forestry programmes in Tanzania. The International Tree Crops Journal, 3, 1-12. http://dx.doi.org/10.1080/01435698.1985.9752784

[40] Chidumayo, E.N. (1988) Estimating fuelwood production and yield in re-growth dry miombo woodland in Zambia. Forest Ecology and Management, 24, 59-66. http://dx.doi.org/10.1016/0378-1127(88)90024-2

[41] Frost, P. and Chidumayo, E.N. (1996) Population biology of miombo trees. In: Campbell, Ed., Miombo in Transition: Woodlands and Welfare in Africa, Centre for International Forestry research, Bogor, 59-71. 
[42] Strang, R.M. (1974) Some man made changes in successsional trends on the Rhodesian Highveld. Journal of Applied Ecology, 111, 249-263. http://dx.doi.org/10.2307/2402019

[43] Chidumayo, E.N., Gambiza, J. and Grundy, I. (1996) Managing miombo woodlands. In: Campbell, Ed., Miombo in Transition: Woodlands and Welfare in Africa, Centre for International Forestry research, Bogor, 175-193.

[44] Winkworth, R.E. (1990) The use of point quadrats for analysis of heath land. Australian Journal of Botany, 3, 68-81.

[45] Strang, R.M. (1966) The spread and establishment of Brachystegia spiciformis and Julbernardia globiflora in the Rhodesian high veld. Commonwealth Forest Review, 253-256.
[46] Gumbo, D.J., Mukamuri, B.B., Muzondo, M.I. and Scoones, I.C. (1990) Indigenous and exotic fruit trees; why do people grow them? In: Prinsley, Ed., Agro Forestry for Sustainable Production: Economic Implications, Common Wealth Scientific Council, London, 185-214.

[47] Ridker, R.G.M. and Cecelski, E.W. (1979) Resource, environment and population: The nature of future limits. Population Bulletin 34, Washington DC., 2-12.

[48] Gumbo, D.J. Makamuri, B.B., Muzondo, M.I. and Scoones, I.C. (1990) Indigenous and exotic fruit trees; why do people plant them? In: Prinsley, Ed., Agroforestry for Sustainable Production: Economic Implications, Commonwealth Scientific Council, London, 185-214.

[49] Wilson, K.B. (1989) Trees in fields in southern Zimbabwe. Journal of Southern African Studies, 15, 369-383. http://dx.doi.org/10.1080/03057078908708205 